\title{
Ground-Water
}

\section{Development in the}

\section{High Plains of Colorado}

GEOLOGICAL SURVEY WATER-SUPPLY PAPER 1819-I

Prepared in cooperation with the Colorado Water Conservation Board

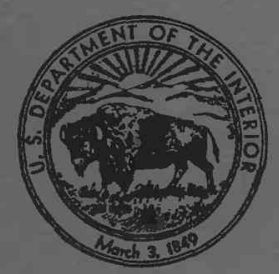




\section{Ground-Water}

\section{Development in the}

\section{High Plains of Colorado}

By ARNOLD J. BOETTCHER

With a section on

CHEMICAL QUALITY OF THE GROUND WATER

By ROBERT BRENNAN

CONTRIBUTIONS TO THE HYDROLOGY OF THE UNITED STATES

GEOLOGICAL SURVEY WATER-S UPPLY PAPER 1819-I

Prepared in cooperation with the Colorado Water Conservation Board

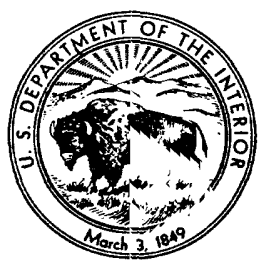




\title{
UNITED STATES DEPARTMENT OF THE INTERIOR
}

STEWART L. UDALL, Secretary

\author{
GEOLOGICAL SURVEY
}

William T. Pecora, Director 


\section{CONTENTS}

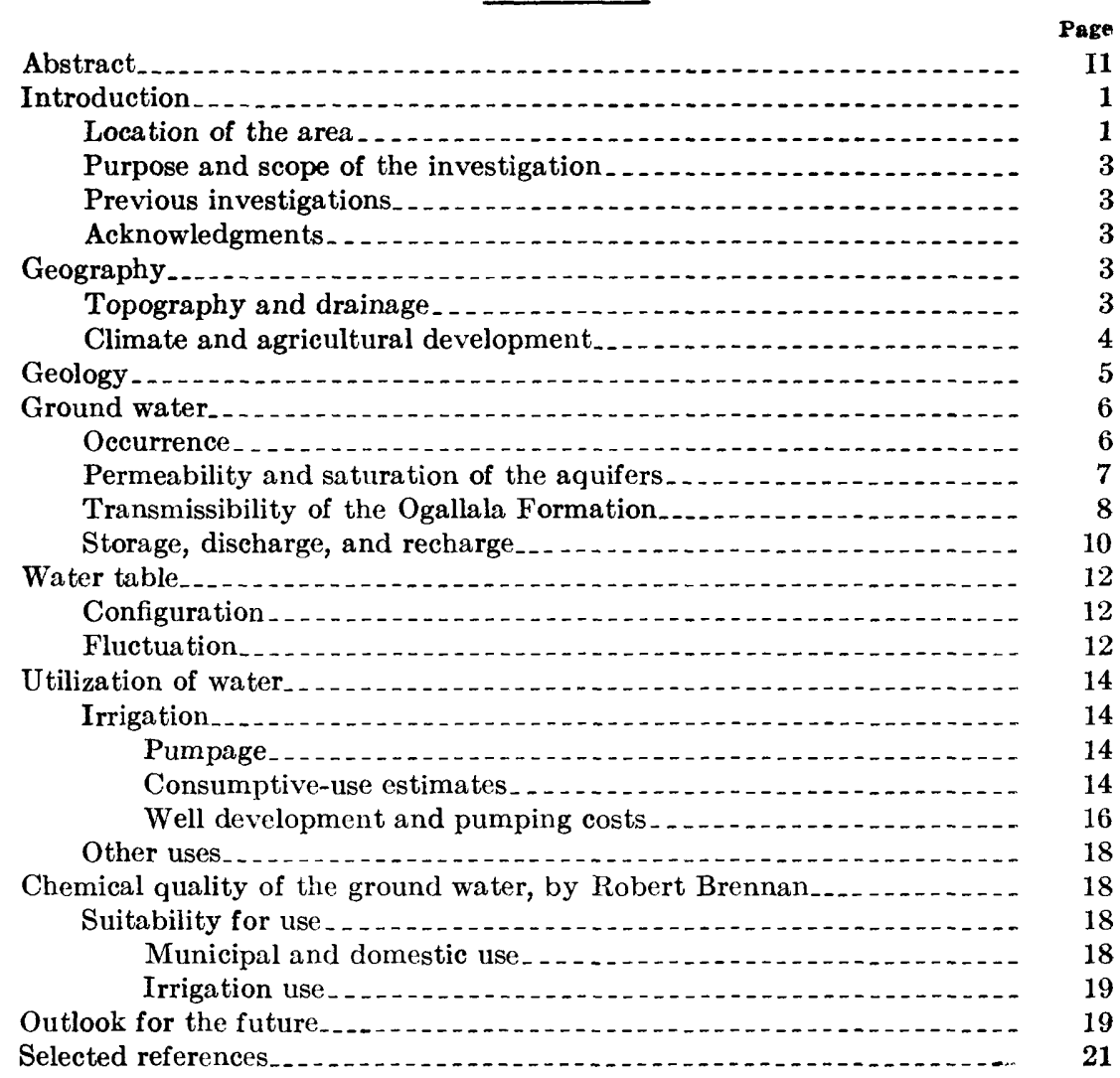

\section{ILLUSTRATIONS}

PuATE 1. Maps showing depth to water in wells and precipitation In pocket

2. Maps showing saturated thickness and transmissibility of materials, water table, and wells................. In pocket

3. Graphs showing irrigation requirements for crops........ In pocket

Figure 1. Index map.

2. Graph showing relation of drawdown and distance from a

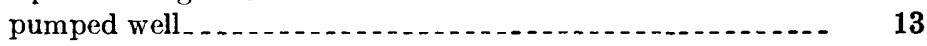

3. Graph showing power costs plotted against lift differences.... 17 


\section{TABLES}

TABLE 1. Acres irrigated and number of irrigation wells used in $1562 \ldots$

2. Summary of aquifer-test results

3. Average range of permeability of materials in the Ogallala Formation

4. Irrigation statistics, 1962

5. Consumptive-use coefficients for crops

6. Average power costs per foot of lift for engines and motors in

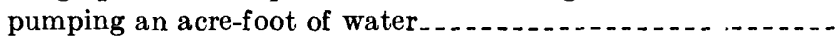




\title{
CONTRIBUTIONS TO THE HYDROLOGY OF THE UNITED STATES
}

\section{GROUND-WATER DEVELOPMENT IN THE HIGH PLAINS OF COLORADO}

\author{
By Arnold J. Boettrcher
}

\begin{abstract}
The High Plains of Colorado includes all or part of 11 counties and has an area of about 9,500 square miles. The land surface slopes eastward and in most areas is gently rolling owing to erosion by ephemeral streams.

The Ogallala Formation, of Pliocene age, is the principal aquifer. In p'aces it is overlain by dune sand, alluvium, or loess. The Ogallala is semiconsclidated and consists of sand, gravel, silt, clay, and caliche.

The Ogallala Formation is recharged by precipitation at a rate of about 0.85 inch per year. The water table slopes generally eastward. The major use of ground water is for irrigation. About 72,500 acre-feet of water was pumped from 428 wells to irrigate about 56,600 acres in 1962 . Estimates of consumptive use made by the Blaney-Criddle method show that the optimum amount of vrater is being used to irrigate parts of the High Plains. At the end of the 1963 irrigation season, 525 irrigation wells each pumped more than 300 gallons per minute. Water levels decline as much as 10 feet in some places during the irrigation season but return almost to normal at the completion of pumping. By prorating transmissibility on the basis of lithologic descriptions from well logs, the average permeability of the Ogallala Formation in various places can be estimated.

Most water from the Ogallala Formation in the High Plains is a calcium bicarbonate solution having a dissolved-solids content ranging from $10 \mathrm{C}$ to 600 parts per million. The water is generally hard; its calcium carbonate hardness ranges from 100 to 350 parts per million. Except for some ground water in the area south of the Cheyenne-Kiowa County line, the ground water analyzed was suitable for all uses.
\end{abstract}

\section{INTRODUCTION}

\section{LOCATION OF THE AREA}

The area discussed is in the High Plains section of the Great Plains physiographic province (Fenneman, 1931); it includes 9,500 square miles-all or part of 11 counties-and is bounded by the State line on the east, the South Platte River on the north, Big Sandy Creek on the west, and the Arkansas River on the south (fig. 1). This area will be referred to as the High Plains of Colorado in this report. 


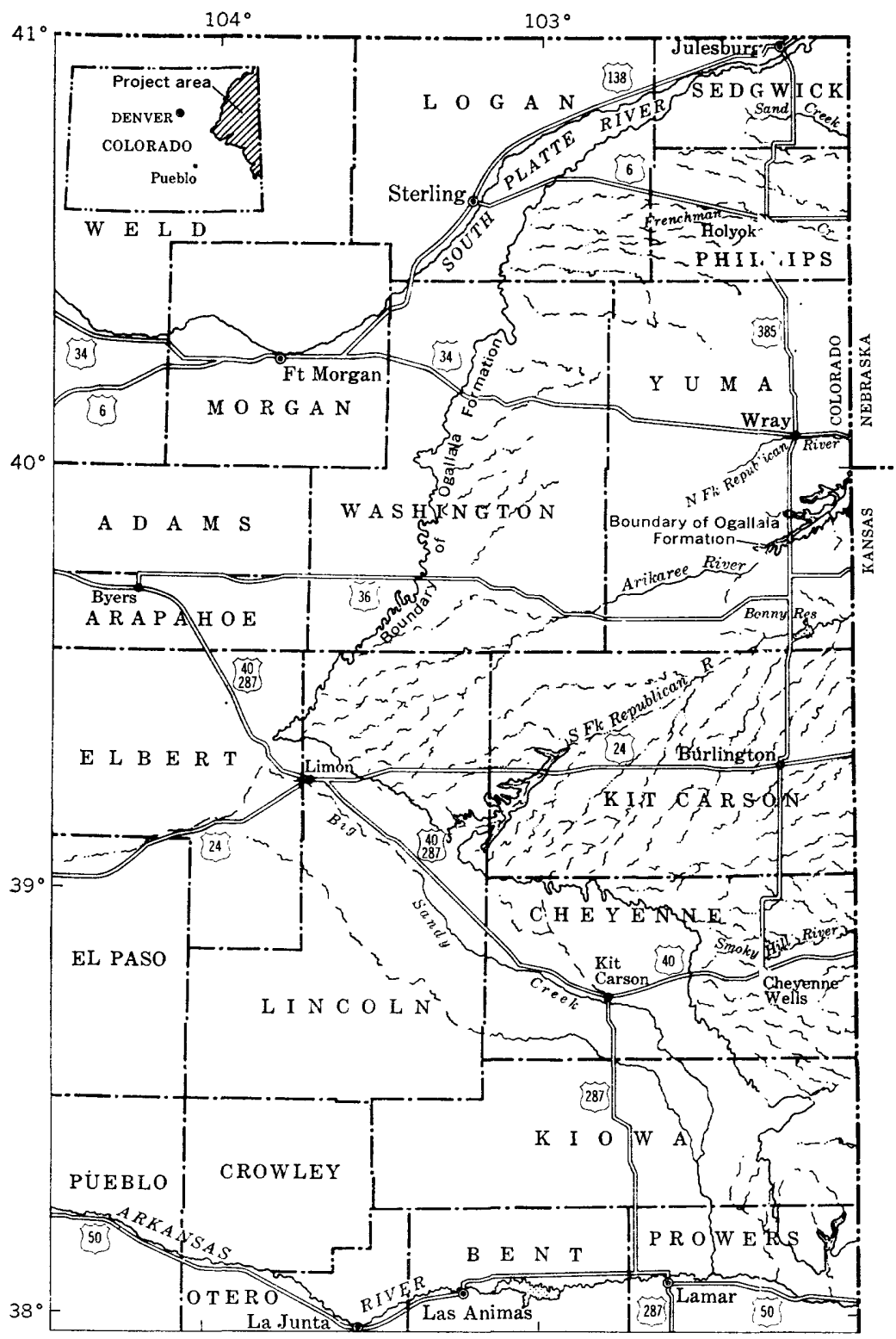

0 50 MILES

Figure 1.-Index map. 


\section{PURPOSE AND SCOPE OF THE INVESTIGATION}

In the early 1960's, drilling of irrigation wells increased in the project area, and the need for an investigation to evaluate the ground-water resources of the High Plains of Colorado was recognized. Ir July 1962 the U.S. Geological Survey in cooperation with the Colorado Water Conservation Board began such a study. The purpose of the study was to compile data collected in previous investigations, to monitor water-level fluctuations, to determine regional pumpage in 1962, to show areas of potential development, and to describe methods of solving water problems or potential water problems.

\section{PREVIOUS INVESTIGATIONS}

The water resources of the project area were first investigated by Hay (1895) ; later, Johnson $(1901,1902)$ reported on the utilization of the High Plains. Darton (1905) included the project are? in a report on the geology and ground-water resources of the Central Great Plains. Cardwell (1953) discussed irrigation-well development in the Kansas River basin of eastern Colorado, which includes most of the project area. Cardwell and Jenkins (1963), Chase (1956), McGovern (1964), and Weist (1964) reported on the geology and ground-water resources of the Frenchman Creek area, Kit Carson, Washington, and Yuma Counties, respectively. The geology and ground-water resources have been investigated in Prowers County by Voegeli and Hershey (1965), and in eastern Cheyenne and Kiowa Counties by Boettcher (1964). A report by Moulder (1960) on ground water in the Ogallala Formation and several consolidated formations ir Colorado includes the project area. McGovern and Coffin (1963) reported on the potential ground-water development of the project area.

\section{ACKNOWLEDGMENTS}

The writer extends his thanks to the well owners who permitted discharge measurements of their wells. He is also grateful to the Soil Conservation Service, who made acreage data available, and to the Highline, K. C., and Y. W. Electric Companies for data on the total kilowatt-hour usage of the electrically driven irrigation pumps.

\section{GEOGRAPHY}

\section{TOPOGRAPHY AND DRAINAGE}

In Colorado the High Plains physiographic section is an eastwardsloping gently rolling plain, in places cut by streams or covered by loess and dune sand. The area north of the Kit Carson-Chayenne County line slopes northeastward; that south of the line slopes generally southeastward. The maximum altitude of the land surface is 
about 5,500 feet, north of Limon; the minimum is about 3,600 feet, north of Holly. The dune sand forms a series of low northwesttrending hills with relatively flat interdune areas. The dunes cover about 1,240 square miles.

The surface of the High Plains is marked by numerous undrained depressions-more than 2,000 in the project area and as many as 20 per square mile in Kit Carson County, the area of greatest density. The depressions, usually dry except after spring rains, range in diameter from a few feet to several thousands of feet. Judson (1950) stated that these depressions in the Ogallala Formation originated from a combination of leaching of calcium carbonate materials in the rock, followed by wind deflation of the leached areas throughout Pleistocene time.

Drainage trends generally eastward and northeastwart. Streams are ephemeral and influent except for the lower reaches of the North and South Forks of the Republican and the Arikaree Rivers, which are effuent near the State line. The area north of Cheyenne Wells is included in the Kansas River basin; the ramainder is included in the Arkansas River basin (fig. 1). Sandy, Patent, and Red Willow Creeks end in the dune sand north of Wray. Because the dune sand is relatively porous, most of the precipitation percolates downward instead of ruming off ; therefore, no definite drainage pattern is established in the sandhill area.

\section{CLIMATE AND AGRICULTURAL DEVELOPMENT}

The climate of the area is semiarid, but conditions are generally favorable for dryland farming in years of normal or above-normal precipitation. Mean annual precipitation ranges from 17.2 inches at Wray to 14.2 inches at Cheyenne Wells. A map showing mean annual precipitation and precipitation for 1962 is given on plate 1; 1962 was an unusually wet year in most of the area. Precipitation is greatest between May and August. Storms are likely to be intense and of short duration, and they cover relatively small areas. Blizzards and severe cold periods are common in winter.

Temperatures average $66^{\circ} \mathrm{F}$ during summer and $33^{\circ} \mathrm{F}$ in winter. The mean annual temperatures range from $50.3^{\circ} \mathrm{F}$ at Holyo're to $52.0^{\circ} \mathrm{F}$ at Cheyenne Wells. The coldest month is January and the warmest is July. The average growing season is about 155 days.

Hot dry winds in the summer remove much of the moisture from the soil. High winds in the spring may blow young plants away or cover them with so much soil that they require replanting.

Agriculture is the main source of income, and irrigation is necessary in most years for certain crops and in some years for all crops; therefore, a stable economy depends largely upon an adequate water supply. Use of ground water for irrigation is beginning to play a 
major part in the agricultural economy in the High Plains of Colorado; the total number of wells and of acres irrigated in 1962 by counties is shown in table 1.

\begin{tabular}{|c|c|c|}
\hline County & $\underset{\text { irrigated }}{\text { Acres }}$ & $\begin{array}{l}\text { Number } \\
\text { of wells }\end{array}$ \\
\hline Kit Carson & 31,862 & 182 \\
\hline Yuma. & 14,011 & 129 \\
\hline Phillips & 3,420 & 30 \\
\hline Washington & 2,707 & 49 \\
\hline Kiowa_............. & 1,170 & 4 \\
\hline Lincoln & 730 & 4 \\
\hline Prowers & 960 & 12 \\
\hline Cheyenne & 941 & 11 \\
\hline Sedgwick & 630 & 4 \\
\hline Logan . & 175 & 3 \\
\hline Elbert. & 0 & 0 \\
\hline Total & 56,606 & 428 \\
\hline
\end{tabular}

The major crops of the 89 square miles irrigated in 1962 are corn and sorghums and smaller amounts of alfalfa. Sugar beets have been grown in the Burlington area since about 1960. Winter whoat and grain sorghums are the two major crops grown under dryland farming methods, winter wheat accounting for 75 percent of the total dryland harvest. All irrigated crops are irrigated from June to September. Alfalfa, however, requires an additional early spring irrigation. Sugar beets are irrigated near Burlington from newly drilled irrigation wells.

\section{GEOLOGY}

The geology of the High Plains of Colorado is not complex. The Ogallala Formation, of Pliocene age, is exposed over most of the area. In some places it is covered by dune sand, loess, or alluvial deposits of Pleistocene and (or) Recent age. The Ogallala is wedge sheped-it slopes generally eastward and ranges in thickness from a few feet on the west to as much as 400 feet in places near the State line.

The Ogallala consists of semiconsolidated poorly sorted sand, silt, clay, gravel, and caliche, and resistant ledges, called mortar be $1 \mathrm{s,} \mathrm{com-}$ posed of sand and gravel cemented with calcium carbonate. The Ogallala is capped in places by algal limestone, a pink concertrically banded rock that was probably formed in shallow lakes at the end of the Pliocene (Elias, 1931, p. 136-141). Sand in the Ogallala is very fine to very coarse and is characteristically buff colored. The gravel is very fine to coarse and is rounded to well rounded. The clay is generally dense and grades from nearly pure to very sandy. The clay beds vary from dark green to dark brown and in places are as much as 20 feet thick. Because these beds are similar to the weathered beds of 
the Upper Cretaceous Pierre Shale or Smoky Hill Shale Member of the Niobrara Formation in drilling characteristics and in color and texture, well drillers may mistake the clay beds of the Ogallala for the weathered surface of the Pierre and Smoky Hill and thus fail to penetrate the Ogallala to its base.

Local variation in thickness of the Ogallala is due primarily to deposition on an undulating bedrock surface. Definite drainage patterns on the bedrock are shown on bedrock contour maps prepared during the course of other studies. The Ogallala increases in thickness regionally west to east primarily because the eastward gradient of the eroded bedrock surface is greater than the eastward dip of the Ogallala surface.

Logs of test holes drilled during previous investigations show that the sand and gravel in the Ogallala generally coarsen with depth. The Pliocene streams flowing across the area carried loads of coarse material derived from the mountains. Subsequent erosion of the finegrained Upper Cretaceous rocks resulted in an increased stream load. Therefore, to maintain stream-load equilibrium, the coarse material was deposited. Later, reworking by streams caused the corrser material to be concentrated near the base of the deposits.

The alluvium, loess, or dune sand that covers the Ogallala Formation in many places varies the geological picture. The alluvium is reworked and eroded material from the Ogallala Formation and is generally better sorted and more permeable than the Ogallala. The loess, consisting of brown to dark-brown silt and very fine to fine sand, is as thick as 50 feet in Kit Carson and Yuma Counties. The dune sand is as thick as 100 feet in some places.

\section{GROUND WATER}

\section{OCCURRENCE}

The Ogallala Formation is the major source of water in the area. Small quantities, 5-20 gpm (gallons per minute), sufficient for stock or domestic supplies, can be obtained from the aquifer almost anywhere. Well yields of 1,000 gpm or more, suitable for irrigation, can be obtained in the east half of Kit Carson County, in northeastern Prowers County, east of Cheyene Wells, in the east half cf Phillips County, and in east-central Washington County. Sufficient water for irrigation cannot be obtained throughout the area becaus? of variations in the aquifer. (See the section on transmissibility.)

Only small quantities of water are supplied by the material covering the Ogallala. Alluvium of most ephemeral streams is above the water table and does not yield water to wells. Irrigation supplias are obtainable, however, in the alluvium of the effluent streams. The dune 
sand yields small amounts of water to wells $(<5 \mathrm{gpm})$. It lies above the water table in many places. The loess deposits are generally above the water table and do not yield water to wells.

\section{PERMEABIIITY AND SATURATION OF THE AQUIFER}

The permeability of a rock and the thickness of the zone of saturation are significant elements in determination of well yields. Variations in permeability and saturation affect movement of water through an aquifer, and data on such variations can be used to calculate well yields.

A permeable rock is one having a texture that permits water to move through it perceptibly under ordinary subsurface gradient. Hydraulic permeability is the capacity of a rock to transmit water under pressure. It may be measured by means of a standard coefficient of permeability-the quantity of water at $60^{\circ} \mathrm{F}$ that flows in a given time under a unit hydraulic gradient through a cross section of unit area. The field coefficient of permeability, which is determined at field temperature, is also used.

Well yields vary with both permeability and saturation. Tho thickness of the zone of saturation is the depth to which the permeable rocks are saturated with water under hydrostatic pressure. In a givon area, the zone of saturation may be thin or thick, depending on toporraphic and geologic conditions. In rocks of high permeability - that is, those of coarser texture which normally have many interconnected openings-a thin zone of saturation may give a surprisingly high well yield. For example, the alluvium is more permeable than the Ogallala Formation, but the zones of saturation are relatively thin. In the alluvium, about 15-20 feet of saturation gives a well yield of about $500 \mathrm{gpm}$; in the Ogallala itself at least 50 feet of saturation is necessary for well yields of $500 \mathrm{gpm}$ or more. Nevertheless, because the zones of saturation in the Ogallala are often much thicker than 50 feet, the actual well yields in the Ogallala are greater than those in the alluvium.

The saturated material above the bedrock ranges in thickness from about 10 to 340 feet, and thickens eastward as shown on plate 2 . Saturation is thickest in northeastern Yuma County and thinnest along the western boundary of the High Plains. The zone of saturation is thin near streams that have cut down to bedrock, except in tro small areas along the Arikaree River near the State line, where saturated alluvium is more than 50 feet thick (not shown on $\mathrm{pl}$. 2). In 55 percent of the area, the saturated thickness of the Ogallala Foundation is 50 feet or more. Dune sand, however, lies at the surface in 13 percent of this area of thick saturation. The dune sand is poorly sorted, and its permeability is thereby reduced. The saturated zone is generally thin. 


\section{TRANSMISSIBILITY OF THE OGALLALA FORMATION}

The ability of an aquifer to transmit water is measured by its coefficient of transmissibility, the amount of water that will flow in a given time under unit hydraulic gradient through a cross section of unit width extending the full thickness of the aquifer. ".hat is, the coefficient of transmissibility is the field coefficient of prrmeability multiplied by the thickness of the aquifer.

The coefficient of transmissibility of the Ogallala Formation as determined from aquifer tests ranges from 20,000 to $250,000 \mathrm{gpd}$ per ft (gallons per day per foot). The wide range of transmissilility is due to variations in grain size, sorting, cementation, compaction, lenticularity, and total saturated thickness of the sand and gravel beds. A transmissibility map based on 49 aquifer tests and the saturatedthickness map is shown on plate 2. Although data are not complete, this map is useful in determining areas where the yield of wells is likely to be high. Results of aquifer tests made in previous investigations are shown in table 2.

The field coefficient of permeability of the Ogallala Formation ranges from 220 to $2,600 \mathrm{gpd}$ per sq $\mathrm{ft}$, as determined from aquifer tests in previous investigations (table 2). This value $\mathrm{r}$ as limited application, however, for it represents the overall average permeability of an ideal aquifer that behaves hydraulically like the aquifer tested. The average permeability may have little physical meaning because, as shown by the well logs, there is a wide range in grain size ind sorting from clay to very coarse gravel, implying a wide range of permeability. A more meaningful value would be the coefficient of permeability for each type of material. Such a value can be calculated by prorating transmissibility on the basis of lithologic descriptions from well logs. The coefficient of permeability of each described unit can be estimated, using a method of prorating based on the following equation:

where

$$
T=\sum P_{i} M_{i}
$$

$T=$ the coefficient of transmissibility;

$P_{i}=$ the coefficient of permeability of each lithologic interval;

$M_{i}=$ the thickness of each lithologic interval.

If a unit permeability is arbitrarily assigned to any lithologic interval and the permeability of other intervals is rated relative to the assigned ralue, the equation may be solved for any interval. 
TABLE 2.-Summary of results of aquifer tests in the High Plains of Colorado [Principal geologic source: Al, alluvium; To, Ogallala Formation]

\begin{tabular}{c|c|c|c|c|c|c|c|c|c|c|c} 
Well & $\begin{array}{c}\text { Princi- } \\
\text { pal } \\
\text { No. } 1 \\
\text { geologic } \\
\text { source }\end{array}$ & $\begin{array}{c}\text { Depth } \\
\text { of well } \\
\text { (feet) }\end{array}$ & $\begin{array}{c}\text { Depth to } \\
\text { water } \\
\text { below } \\
\text { land } \\
\text { surface } \\
\text { (feet) }\end{array}$ & $\begin{array}{c}\text { Total } \\
\text { satu- } \\
\text { rated } \\
\text { thick- } \\
\text { ness } \\
\text { (feet) }\end{array}$ & $\begin{array}{c}\text { Dura- } \\
\text { tion } \\
\text { (hours) }\end{array}$ & $\begin{array}{c}\text { Average } \\
\text { rate } \\
\text { (gpm) }\end{array}$ & $\begin{array}{c}\text { Pumping } \\
\text { down } \\
\text { (feet) }\end{array}$ & $\begin{array}{c}\text { Sapacity } \\
\text { (gpm per } \\
\text { ft) }\end{array}$ & $\begin{array}{c}\text { Coeffi- } \\
\text { cient of } \\
\text { trans- } \\
\text { missibil- } \\
\text { ity (gpd } \\
\text { per ft) }\end{array}$ & $\begin{array}{c}\text { Field co- } \\
\text { efficient } \\
\text { of per- } \\
\text { meabil- } \\
\text { ity (gpd } \\
\text { per sq ft) }\end{array}$ \\
\hline
\end{tabular}

\begin{tabular}{|c|c|c|c|c|c|c|c|c|c|c|}
\hline \multicolumn{11}{|c|}{ Cheyenne County } \\
\hline $1 \ldots \ldots$ & To...... & 255 & 148 & 105 & 225 & 1,445 & 27 & 54.3 & 87,000 & 830 \\
\hline
\end{tabular}

\begin{tabular}{r|r|r|r|r|r|r|r|r|r|r|r|r|r|r|r|}
\hline $2 \ldots 7$ & 93 & 98 & 9 & 1,340 & 25 & 120,000 & 1,200 \\
\hline
\end{tabular}

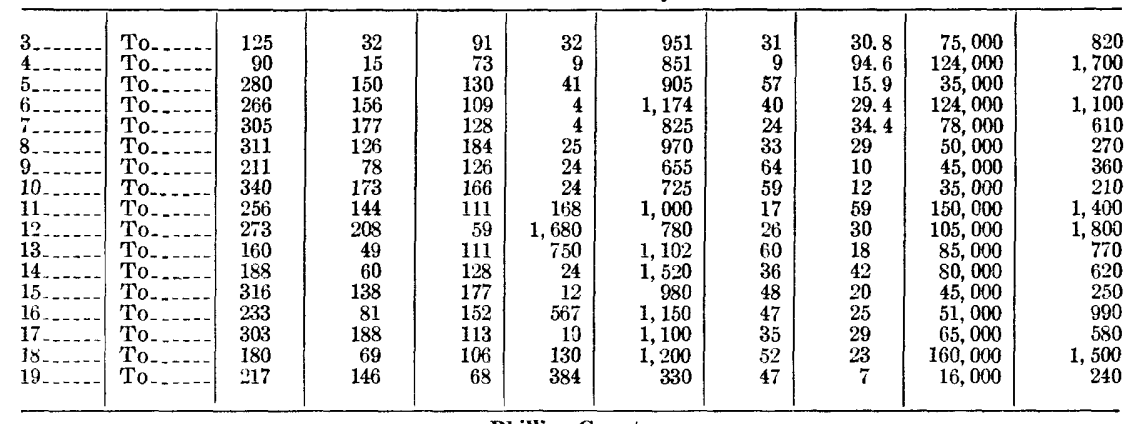

\begin{tabular}{|c|c|c|c|c|c|c|c|c|c|c|}
\hline \multicolumn{11}{|c|}{ Phillips County } \\
\hline $\begin{array}{l}20 \ldots \ldots \\
21 \ldots \ldots \\
22-\ldots- \\
23 \ldots \ldots-\end{array}$ & $\begin{array}{l}\text { To.... } \\
\text { To_. } \\
\text { To. } \\
\text { To. }\end{array}$ & $\begin{array}{l}230 \\
215 \\
236 \\
198\end{array}$ & $\begin{array}{l}93 \\
60 \\
59 \\
48\end{array}$ & $\begin{array}{l}190 \\
238 \\
254 \\
254\end{array}$ & $\begin{array}{r}13 \\
121 \\
359 \\
11\end{array}$ & $\begin{array}{r}740 \\
1,410 \\
800 \\
1,170\end{array}$ & $\begin{array}{r}7 \\
19 \\
11 \\
10\end{array}$ & $\begin{array}{r}106 \\
74 \\
73 \\
117\end{array}$ & $\begin{array}{l}230,000 \\
160,000 \\
200,000 \\
270,000\end{array}$ & $\begin{array}{r}1,200 \\
570 \\
790 \\
1,100\end{array}$ \\
\hline
\end{tabular}

\begin{tabular}{l|r|r|r|r|r|r|r|r|r|r}
\hline & \multicolumn{7}{c}{ Sedg wick County } \\
\hline $24 \ldots$ & To..... & 400 & 231 & 151 & 6 & 1,030 & 43 & 24 & 40,000 & 260 \\
\hline
\end{tabular}

\begin{tabular}{|c|c|c|c|c|c|c|c|c|c|c|}
\hline 28 & To....... & 254 & 86.1 & 168 & 10 & 1,050 & 10 & 105 & 220,000 & 1,300 \\
\hline 29. & T'o & 314 & 101.8 & 212 & 3 & 1,440 & 17 & 85 & 230,000 & 1,100 \\
\hline 30 & To. & 140 & 29.1 & 111 & 5 & 480 & 36 & 13 & 30.000 & 270 \\
\hline 31. & To $\ldots$ & 421 & 179.7 & 240 & 4 & 895 & 17 & 53 & $110,00 \mathrm{C}$ & 460 \\
\hline 32 & To........ & 118 & 26.7 & 91 & 4 & 300 & 23 & 13 & $30.00 \mathrm{C}$ & 330 \\
\hline 33 & To. & 314 & 133.0 & 181 & 24 & 1,060 & 21 & 50 & $120,00 \mathrm{C}$ & 660 \\
\hline $34 \ldots$ & To.. & 298 & 184.6 & 103 & 14 & 440 & 24 & 18 & $25,00 \mathrm{C}$ & 260 \\
\hline 35. & To. & 260 & 17.8 & 242 & 33 & 1,800 & 27 & 67 & $250,00 \mathrm{C}$ & 1,000 \\
\hline 36 & To. & 318 & 157.0 & 161 & 29 & 650 & 42 & 15 & $35,00 \mathrm{r}$ & 220 \\
\hline $3 \bar{r}$ & To & 263 & 113. 3 & 150 & 2 & 1,310 & 28 & 47 & $105,00 \leftarrow$ & 710 \\
\hline $38 \ldots$ & To.. & 197 & 53.9 & 143 & 13 & 865 & 21 & 41 & $80,00 \mathrm{C}$ & 560 \\
\hline 39. & To.... & 236 & 173. 2 & 63 & 25 & 350 & 43 & 8 & $20,00 \mathrm{C}$ & 320 \\
\hline $40 \ldots$ & To $\ldots$ & 281 & 185. 9 & 95 & 10 & 1,100 & 70 & 16 & $40,00 c$ & 420 \\
\hline $41 \ldots$ & To & 300 & 187. 0 & 113 & 31 & 540 & 14 & 39 & $95,00 \mathrm{C}$ & 840 \\
\hline 42. & To...... & 295 & 195.9 & 99 & 10 & 750 & 48 & 16 & 40,000 & 400 \\
\hline 43. & Al.. & 27 & 14.8 & 12 & 2 & 400 & 5 & 80 & 120,000 & 10,000 \\
\hline 44. & To. & 260 & 97.7 & 162 & 10 & 1,160 & 14 & 83 & 250,000 & 1,500 \\
\hline 45. & Al. & 53 & 11.9 & 41 & 10 & 420 & 17 & 25 & 65,000 & 1,600 \\
\hline 46 & Al & 74 & 19.8 & 54 & 2 & 470 & 10 & 47 & $100,00 \mathrm{C}$ & 1,900 \\
\hline 47 & AI, To... & 85.6 & 25.4 & 60 & 20 & 775 & 20 & 39 & 100,000 & 1,700 \\
\hline 48. & To & 240 & 97.7 & 142 & 10 & 1,275 & 14 & 91 & 200,000 & 1,400 \\
\hline 49 & To.. & 281 & 114.2 & 167 & 26 & 870 & 29 & 30 & 60,000 & 360 \\
\hline
\end{tabular}

1 Location of wells is shown on plate 2.

2 Specific capacity is the well yield, in gallons per minute per foot of drawdown. 
Table 3 shows the coefficient of permeability for common materials in the Ogallala Formation. This information can be used to estimate

TABLE 3.-Average range of permeability of materials in the Ogallala Formation

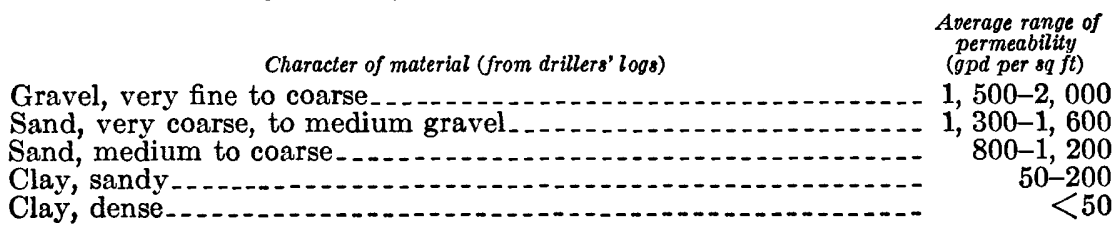

the transmissibility, which in turn can be used to calculate the yield of a test hole or well before a pump is installed. To estimate the discharge of a test well, the thickness of the saturated material in each bed described in the driller's log is multiplied by the appronriate permeability from table 3 ; these values are then added to give an estimated coefficient of transmissibility. A drawdown that will not dewater more than 50 percent of the saturated thickness is then selected. If zero drawdown at 10,000 feet and a well radius of 1 foot are assumed, the Thiem equation (Ferris and others, 1962, p. 91) may be approximated as follows:

where

$$
\begin{aligned}
& T=\frac{(2000) Q}{s} \\
& Q=\frac{T s}{2000}
\end{aligned}
$$

$T=$ coefficient of transmissibility, in gallons per day per foot;

$Q=$ discharge of pumped well, in gallons per minute;

$s=$ drawdown in pumped well, in feet.

If the estimated coefficient of transmissibility for the test rell is substituted in equation 2 , the expected yield can be estimated.

\section{STORAGE, DISCHARGE, AND RECHARGE}

Fluctuations in the amount of water present in an aquifer may be measured by various methods. The volume of water an squifer releases from or takes into storage per unit of surface area of the aquifer, per unit change in the component of head normal to that surface, is called the coefficient of storage. (The component of head is the pressure exerted by the water at that point, expressed as the boight of a column of water that can be supported by the pressure.)

Aquifer tests of the Ogallala Formation indicate that the coefficient of storage ranges from 0.01 to 0.20 . These tests cover relatively short periods and are therefore subject to certain errors. Longar tests of the Ogallala Formation of the High Plains of Texas indicate that the coefficient of storage approaches 0.15 (Cronin and Wells, 1963, p. U15- 
U20; Moulder and Frazor, 1957, p. 12-17). Until further drta are available for the High Plains of Colorado, the 0.15 figure is assumed to be realistic.

Ground water is discharged by wells, streams, transpiration, evaporation, and subsurface underflow. A total of about 82,000 acre-feet of water was pumped in 1962, and about 40,000 acre-feet was discharged by streams.

Most evapotranspiration of ground water is from areas where the depth to water is less than 10 feet; the total discharge of ground water by evapotranspiration is relatively small. The roots of most grasses and grains do not extend more than a few feet vertically, but alfalfa may use water from depths as great as 20 feet.

Evaporation is greatest in summer because of high temperatures, low humidity, and high winds. As summer coincides with the irrigation season, some irrigation water is evaporated before it reaches the crops.

Discharge by underflow across the State line was estimated to be 390,000 acre-feet annually (McGovern and Coffin, 1963, p. 6). The hydraulic system is assumed to be in equilibrium, and recharge is considered to be equal to discharge. Therefore, if the total discharge of streams $(40,000$ acre- $\mathrm{ft})$ is added to the total discharge by underflow $(390,000$ acre-ft), the total annual natural discharge and recharge is 430,000 acre-feet. The water pumped from wells is taken from storage, except for a negligible amount, and does not significantly affect underflow.

The Ogallala Formation is recharged by precipitation on the outcrop or on overlying alluvium or dune sand. The amount differs from place to place because of differences in the topography, vegetation, soil, and agricultural practices. Permeability of the rock, the depth to water, and the intensity and duration of precipitation also af ect the amount of recharge. Where thick loess $(>20 \mathrm{ft})$ overlies the Ogallala, recharge is small because the vertical permeability of loess is low. In areas overlain by dune sand and alluvium, the Ogallala js more readily recharged, and little water runs off. Recharge to the aquifer per unit area is probably greatest in deposits underlying ephemeral streams; however, total recharge to the Ogallala is greatest in the dune-sand areas because of their larger areal extent.

Recharge varies with the intensity and duration of precipitation. During a storm, many parts of the High Plains receive a substantial amount of precipitation, whereas others receive none, as shown by the pattern of precipitation in 1962 (pl. 1). The type of precipit tion is significant in recharge; long gentle rain is more effective in replenishing soil moisture than short intense rain, but short intense rain results in runoff in ephemeral streams, where recharge through permeable channel deposits may be relatively great. 
If recharge is assumed to equal discharge, the average annual recharge over the 9,500 square miles is 430,000 acre-feet fer year, or 0.85 inch per year. Recharge to the Ogallala Formation ranges from almost zero in the loess-covered areas to more than 2 inches per year in the dune-sand areas, as determined by the finite-difference method (Ferris and others, 1962, p. 136-138) and aquifer tests. Small recharge areas, such as the sinkholes and areas covered by alluvium, are difficult to detect with available data by the finite-difference method.

\section{WATER TABLE}

\section{CONFIGURATION}

Water-table contours depict the configuration of the water table as topographic contours do that of the land surface. The weter table is neither level nor uniform but slopes irregularly, and ground water moves generally at right angles to the contours in the direction of greatest slope of the water table. Large withdrawal of ground water is indicated by flexures of water-table contours, as is erident near Burlington and Cheyenne Wells on plate 2.

The water table generally slopes eastward (pl. 2); its slope is influenced by the transmissibility of the aquifer, the configuration of the bedrock, and the rate of recharge and discharge. Where the watertable contours are closely spaced, the transmissibility is low or the bedrock dips steeply.

A bedrock high influences the movement of ground water just south of the Cheyenne-Kit Carson County line. The direction of movement, at right angles to the contours, is away from the high. The water-table contours at the Yuma-Phillips County line are farther apart and probably indicate high transmissibility of the aquifer.

In broad outline the water table conforms with the configuration of the bedrock surface along the west flank of the project area. Seeps occur along the west edge of the area, because in a few places the bedrock surface dips westward and water seeps out of tho Ogallala Formation.

The depth to water in the Ogallala Formation ranges from about 10 to 300 feet (pl. 1). Depth to water is significant in well development, because as the depth to water increases, the amount of energy consumed in pumping also increases.

\section{FLUCTUATION}

The rise and decline of the water table is caused by variations in recharge, discharge, and barometric pressure. The water table fluctuates more by addition or subtraction of a given quantity of water than does the water surface of a reservoir. If the Ogallala Formation has a storage coefficient of 0.15 (see p. I 11), the addition or sub- 
traction of 1 foot of water in the aquifer will change the level of the water table more than 6 feet.

The degree of rise of the water table is dependent on the rmount of precipitation that percolates downward to the water table. In general, the Ogallala Formation is recharged slowly, so the lag between the time the water enters the soil and the time it reaches the water table is relatively great.

A water-table decline caused by pumping on the High Plains is evident immediately near the pumped well, and the decline expands outward with time. After a high-capacity well tapping the Ogallala Formation has been pumped for the irrigation season, a decline (as much as $10 \mathrm{ft}$ ) may be evident as far as 2,000 feet from the well. Figure 2 is a plot of drawdown against distance from a pumping well for different lengths of time. In winter, when irrigation wells are not pumped, the water table returns almost to its prepumping level, and the yearly decline caused by pumping in a particular ar a may be too small to be noticeable. The degree of decline depends on the amount pumped and the storage capacity of the aquifer.

Changes in barometric pressure also cause the water level to fluctuate in wells, because the depth to water is more than 100 feel in most of the area and because layers of dense clay act as partial confining beds. Water levels decline as barometric pressure ir creases

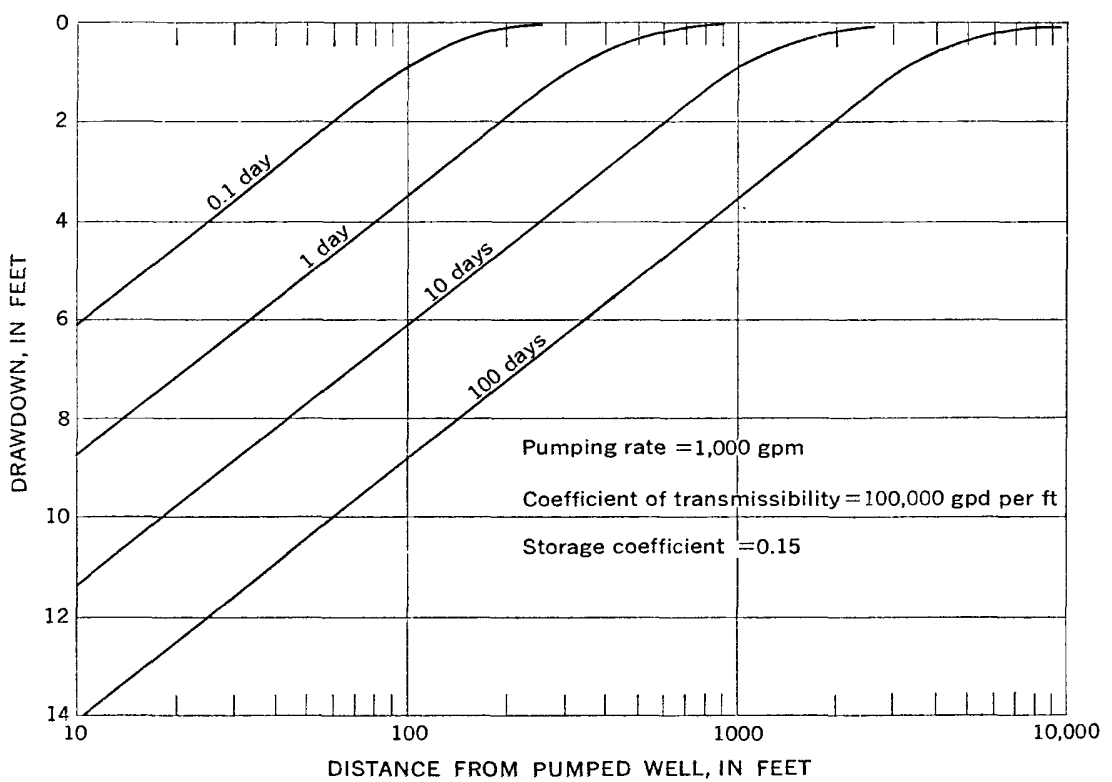

Figure 2.-Relation of drawdown and distance from a pumped well. 
and rise when it decreases. Water-level changes as great as 1 foot in 2 days have been attributed to changes in barometric pressure, as recorded in Cheyenne County (Boettcher, 1964).

The water-table fluctuation in 1962 was as much as 3 feet in observation wells measured in the spring and fall. In summer the water table has declined as much as 3 feet in parts of Phillips and Yuma Counties and as much as 10 feet in northeastern Prowers and southeastern Kiowa Counties, but it has returned to the prepumping level after the completion of the irrigation season. The water table has declined 2-3 feet in eastern Kit Carson County since 195: because of increased pumping. Water levels have been monitored for as long as 10 years in Phillips, Sedgwick, and Yuma Counties, and for 3 years in the entire area. At present (1963), 65 observation vells in the area are being measured semiannually by the U.S. Geological Survey and Colorado State University.

\section{UTILIZATION OF WATER}

\section{IRRIGATION}

\section{PUMPAGE}

The use of water for irrigation purposes in the Higl Plains of Colorado may be estimated from pumpage data, since most. irrigation water in the area is supplied by wells. In 1962 about 72,590 acre-feet of ground water was pumped for irrigation in the project area, as shown in table 4. The pumpage for electrically powered wells was determined from power records, and the amount of water applied per acre was calculated. Assuming the same amount of water per acre is applied in each county by liquefied petroleum gas, gasoline, and diesel-driven pumps as by electrically driven pumps, then total pumpage is the product of water applied per acre and total irrigated area. At the time of this writing (1963) 525 irrigation wells yield more than $300 \mathrm{gpm}$ each; 112 were drilled between 1961 and 1963. Most new wells were drilled near Burlington (pl. 2).

Most of the irrigation wells are equipped with vertical turbine pumps, but some of the older wells are equipped with centrifugal pumps. The pumps are generally powered by liquefied petroleum gas engines, electric motors, or natural gas engines. A few c $f$ the older wells are powered by gasoline or diesel-fuel engines.

\section{CONSUMPTIVE-USE ESTIMATES}

In considering water needs for irrigation, it is valuakle to make estimates from another point of view. The amount of irrigation water necessary to grow crops depends on the prevailing conditions of 
TABLe 4.-Irrigation statistics for the High Plains of Colorado (1562)

[Data for acres irrigated obtained from County Soil Conserv. Service, U.S. Dept. Agriculture, or landowner]

\begin{tabular}{|c|c|c|c|c|c|c|c|}
\hline County & $\begin{array}{c}\text { Number } \\
\text { of irriga- } \\
\text { tion } \\
\text { wells } 1\end{array}$ & $\begin{array}{l}\text { Number } \\
\text { of irriga- } \\
\text { tion } \\
\text { wells } \\
\text { used }\end{array}$ & $\begin{array}{c}\text { Acres } \\
\text { irrigated }\end{array}$ & $\begin{array}{c}\text { A verage } \\
\text { number of } \\
\text { acres irri- } \\
\text { gated per } \\
\text { well }\end{array}$ & $\begin{array}{l}\text { Estimated } \\
\text { acre-feet } \\
\text { of water } \\
\text { per acre } \\
\text { irrigated }\end{array}$ & $\begin{array}{l}\text { Estimated } \\
\text { average } \\
\text { pumpage } \\
\text { per well } \\
\text { (acre-ft) }\end{array}$ & $\begin{array}{c}\text { Estimated } \\
\text { acre-feet } \\
\text { of ground } \\
\text { v'ater used } \\
\text { for irriga- } \\
\text { tion }\end{array}$ \\
\hline $\begin{array}{l}\text { Kit Carson } \\
\text { Yuma. } \\
\text { Phillips } \\
\text { Washington } \\
\text { Kiowa. } \\
\text { Cheyenne. } \\
\text { Lincoln } \\
\text { Prowers } \\
\text { Sedgwick } \\
\text { Logan }\end{array}$ & $\begin{array}{r}265 \\
135 \\
30 \\
54 \\
4 \\
12 \\
5 \\
12 \\
5 \\
3\end{array}$ & $\begin{array}{r}182 \\
129 \\
28 \\
49 \\
4 \\
11 \\
4 \\
12 \\
4 \\
3\end{array}$ & $\begin{array}{r}31,862 \\
14,011 \\
3,420 \\
2,707 \\
1,170 \\
941 \\
730 \\
960 \\
630 \\
175\end{array}$ & $\begin{array}{r}175 \\
109 \\
122 \\
55 \\
293 \\
86 \\
183 \\
80 \\
158 \\
58\end{array}$ & $\begin{array}{l}1.4 \\
1.0 \\
1.3 \\
1.5 \\
1.3 \\
1.1 \\
1.0 \\
1.0 \\
1.3 \\
1.1\end{array}$ & $\begin{array}{r}246 \\
109 \\
161 \\
82 \\
375 \\
91 \\
175 \\
83 \\
200 \\
67\end{array}$ & $\begin{array}{r}44,800 \\
14,000 \\
4,500 \\
4,000 \\
1.500 \\
1,000 \\
700 \\
1,000 \\
800 \\
200\end{array}$ \\
\hline Total .......... & 525 & 428 & 56,606 & -- & & & 72,500 \\
\hline
\end{tabular}

1 Includes irrigation wells drilled since end of 1962 growing season to February 1963.

rainfall, wind, sunshine, temperature, and humidity; on the nature of soil ; and on management practices. Blaney and Criddle (1950) devised a method whereby the potential consumptive use of weter by most crops can be estimated from climatologic data that take rost of the above criteria into consideration. The method utilizes the following equation:

where

$$
u=K f
$$

$u=$ the potential consumptive use, in inches per growing season; $K=$ a consumptive-use coefficient of the crop;

$f=$ the mean temperature multiplied by percentage sunshine (from U.S. Weather Bur. records) in the growing period for the crop.

Table 5 shows the consumptive-use coefficients and the length of growing season for crops in the High Plains of Colorado. Thus, tl e irrigation requirement is the potential consumptive use minus the effective rainfall.

TABLE 5.-Consumptive-use coefficients for crops in the High Plains of Colorado [Data obtained from Blaney and Criddle (1950)]

Crop

Corn

Alfalfa

Grain sorghums
Length of growing season

4 months

Between frosts

4-5 months

\section{Consump-} tive-use
coefficient

0.85

.85

.70

Plate 3 shows the irrigation requirement for corn, alfalfa, and grain sorghums, computed from climatologic data applicable to the Akron, Burlington, Cheyenne Wells, Holyoke, and Wray areas. Irrigation 
practices in the project area indicate that about 25 percent of the water leaks from the ditches or evaporates before it gets to the crop. By the Blaney-Criddle method, the total amount of water consumed by the irrigated crops in 1962 was found to be 70,000 acre-feet. This figure compares closely with the estimated 72,500 acre-feet of water used for irrigation as shown in table 4. Apparently, irrigators are using about the optimum amount of water to grow crops.

\section{WHIL DEVELOPMENT AND PUMPING COSTS}

Most of the large-capacity wells were drilled by hydraulic-rotary or reverse-rotary methods. The hydraulic-rotary method is generally used for drilling wells less than 12 inches in diameter, and the reverserotary method for wells of larger diameter.

Wells tapping the Ogallala Formation and the alluvium are cased the full length of the hole to bedrock to prevent caving. The casing should be perforated or screened opposite the coarsest materials in the aquifer. If the perforations are too large, fine sand filters through them; pumps may be damaged, or yields may decline. If the perforations are too small, they may become clogged, and increasec. drawdown with decreased yield results.

The perforation or screen size may be determined with respect to size and degree of sorting of the materials in the aquifer. If the well is properly developed, a screen size that passes $60-80$ percent of the finer materials and retains the coarse materials greatly increases the effective diameter of the well and increases the capacity.

To obtain the maximum yield from a well at the low st possible cost, the well screen or perforated casing should be proper!y designed, and the well should be adequately developed after drilling is completed and casing installed.

The cost of pumping ground water depends on the following factors: (1) The quantity pumped, (2) the total head, (3) the cost of power, (4) the cost of maintenance, (5) the efficiency of the powerplant (electric motor or internal combustion engine), and (6) the efficiency of the pump. Table 6 shows the average power costs for all types of power used; an overall efficiency of 66 percent for the powerplant and pump is assumed. The efficiency might $k \rightarrow$ much less than 66 percent, even as low as 15 percent if the powerplart is in poor condition. The cost per acre-foot per foot of lift for a pump and powerplant having an overall efficiency of 22 percent would be three times that shown in table 6 . For comparable age and use, electric motors decrease in efficiency much more slowly than internal combustion engines. Sand pumped with water also reduces the ef ciency of a pump in a short time. In many places, the type of fuel or energy available determines the type of powerplant, thus limiting the choice 
TABLE 6.-Average power costs per foot of lift for engines and motors in purping an acre-foot of water

[Horsepower hours required at pump shaft ${ }^{1]}$

\begin{tabular}{|c|c|c|c|c|c|c|}
\hline Type of power or fuel & $\begin{array}{l}\text { Unit of power } \\
\text { or fuel }\end{array}$ & $\begin{array}{c}\text { Horsepower } \\
\text { hours per } \\
\text { unit of } \\
\text { power or } \\
\text { fuel }\end{array}$ & $\begin{array}{l}\text { Number of } \\
\text { units of } \\
\text { power or } \\
\text { fuel used to } \\
\text { operate } 2.08 \\
\text { horsepower }\end{array}$ & $\begin{array}{l}\text { Average } \\
\text { cost per } \\
\text { unit of } \\
\text { power or } \\
\text { fuel } \\
\text { (cents) }\end{array}$ & $\begin{array}{c}\text { A verage } \\
\text { cost per } \\
\text { horsepower } \\
\text { hour } \\
\text { (cents) }\end{array}$ & $\begin{array}{l}\text { Cost per } \\
\text { acre-foot of } \\
\text { water per } \\
\text { foot of lift } \\
\text { (cents) }\end{array}$ \\
\hline $\begin{array}{l}\text { Electric } \\
\text { Gasoline } \\
\text { Diesel } \\
\text { Liquefied petroleum gas } \\
\text { Natural gas }\end{array}$ & $\begin{array}{l}\text { Kilowatt-hour } \\
\text { Gallon } \\
1,000 \text { cu ft }\end{array}$ & $\begin{array}{r}21.21 \\
311.55 \\
314.58 \\
39.18 \\
388.9\end{array}$ & $\begin{array}{r}1.72 \\
.18 \\
.14 \\
.23 \\
23.0\end{array}$ & $\begin{array}{l}43.19 \\
22 \\
17 \\
11 \\
.039\end{array}$ & $\begin{array}{l}2.63 \\
1.90 \\
1.14 \\
1.22 \\
.43\end{array}$ & $\begin{array}{l}5.49 \\
3.96 \\
2.38 \\
2.53 \\
.90\end{array}$ \\
\hline
\end{tabular}

1 Horsepower hours = gallons per acre-foot times lift (feet). times weight of water (pounds per gallon), divided by foct-pounds per minute times length of test (minutes), times overall efficiency (computation based on an overall efficiency of 66 percent).

$$
=\frac{325,850 \times 1 \times 8.33}{33,000 \times 60 \times 0.66}=2.08
$$

2 Data from electric motors within the area.

3 Data from tractor-testing laboratory, Nebraska Univ. Agr. Expt. Sta. (Frolik, 1963).

1 Includes service charge.

by irrigators. Figure 3 shows the cost of different types of fuel and energy in relation to the height of lift. This graph does not include investment, maintenance, or repair costs. These costs, as well as power costs, should be considered before any powerplant is obtained. Convenience and dependability are other considerations.

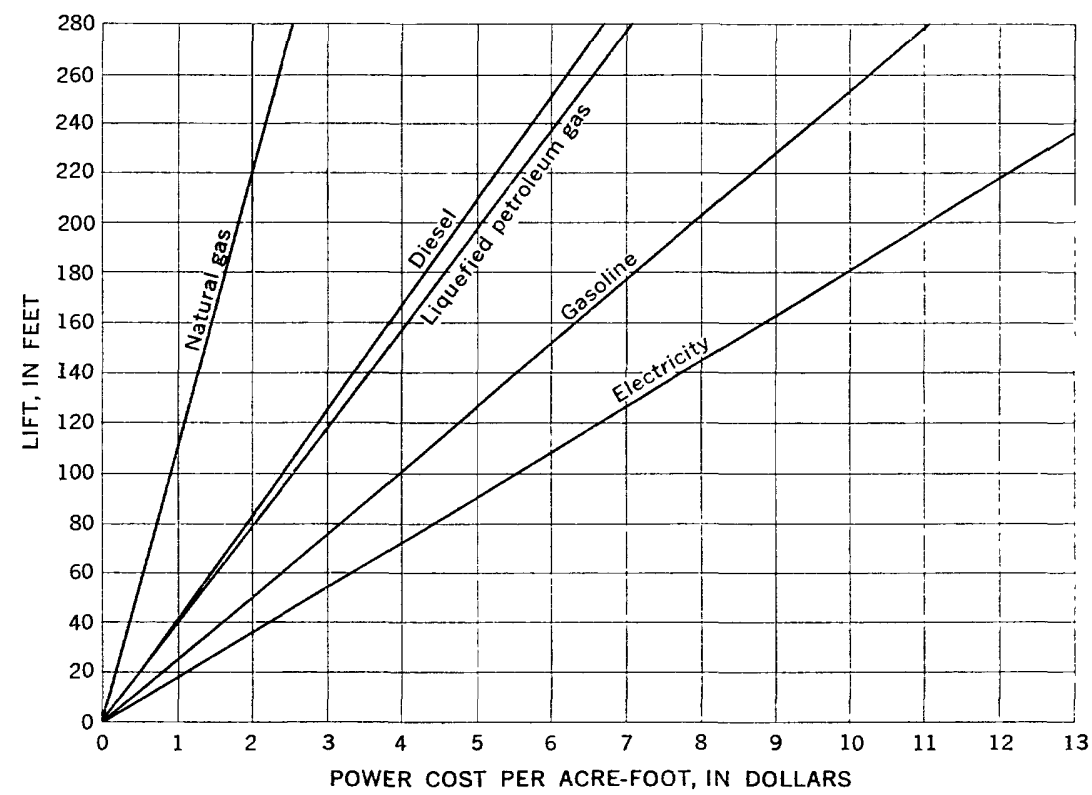

Figure 3.--Power costs, assuming 66 percent overall efficiency in prump and powerplant, plotted against lift differences for various types of power used in irrigation wells. 


\section{OTHER USES}

The municipalities in the area obtain their water from the Ogallala Formation. Their annual pumpage is about 5,000 acre-feet, as computed from data by Gregg, Meyer, Targy, and Moulder (1961). The Ogallala Formation is the only source of water for domestic uses and the major source for stock uses. About 5,000 acre-feet of water annually is pumped for domestic and stock wells. The location of municipal wells is shown on plate 2 .

\section{CHEMICAL QUALITY OF THE GROUND WATER}

\section{By Robert Brentan}

The Ogallala Formation, the principal aquifer, yields large quantities of water to wells. This water is generally of good to excellent quality. Water from the Ogallala is generally of the calcium bicarbonate type and has a dissolved-solids content ranging from 100 to $600 \mathrm{ppm}$. Calcium and magnesium are the principal constituents producing hardness, and the water ranges from moderately hard to very hard (100-350 ppm calcium carbonate). In places the water is of the calcium sulfate type and is of poor quality. This water is associated with the alluvium along the main streams and with areas of minimum saturated thickness of the Ogallala along the west edge of the High Plains and south of the Cheyenne-Kiowa County line. The poor quality of this water is attributed to the underlying bedrock, which contains soluble crystals of gypsum.

\section{SUITABILITY FOR USE}

Ground water is used principally for municipal, domestic, and irrigation supplies. Most of the communities have municip l systems, but people living outside these communities obtain their water from individual wells.

The standards used in this report for municipal or domestic water are those of the U.S. Public Health Service (1962). Standards for irrigation water are those of the Salinity Laboratory Staff (1954).

\section{MUNICIPAL AND DOMESTIC USE}

Ground water north of the Cheyenne-Kiowa County line is of suitable quality for municipal and domestic use. The dissclved-solids content is less than the recommended maximum of $500 \mathrm{pp} \mathrm{m}$, and the concentration of individual constituents is also below the recommended maximum limits. The water, however, is classed as moderately hard to very hard (100-350 ppm calcium carbonate). Some softening, therefore, may be desirable. 
South of the Cheyenne-Kiowa County line, dissolved solids exceed the recommended limit of $500 \mathrm{ppm}$, amounting to more than $1,090 \mathrm{ppm}$ in places. Water from many of the wells exceeds the recommended limit of $250 \mathrm{ppm}$ sulfate content and is classed as very hard. In places, sulfate content and hardness are greater than 1,000 ppm.

\section{IRRIGATION USE}

Factors such as soil texture, permeability, drainage, cropping patterns, and management practices affect the suitability of water for irrigation. The criteria used in this report assume that soil texture, permeability, and drainage are average and that management "s good.

Almost all irrigation is concentrated north of the Cheyenne-Kiowa County line, where wells having sufficient yields for irrigation can be developed most easily. In that area, all the ground water th at was analyzed is suitable for irrigation. It has a very low sodium hazard, so it can be used on most soils with little danger of developing harmful levels of exchangeable sodium in the soils. Generally, the ground water has a medium salinity hazard; moderate amounts of leaching should be satisfactory and crops with a moderate salt tolerance, such as wheat, oats, corn, alfalfa, and most truck crops, can be grown without special salinity control. The boron concentration is low and therefore is not likely to be toxic to plants.

South of the Cheyenne-Kiowa County line, several water samples analyzed had a high to very high salinity hazard. Major irrigation is not practiced in this area as yet and probably never will be practiced because the aquifer is generally less than 10 feet thick.

\section{OUTLOOK FOR THE FUTURE}

Ground water beneath the High Plains of Colorado is one of the State's great potential economic assets awaiting development. The only certain prediction that can be made is that this asset will be developed and that the development will result in declining water levels. Prediction of the numerous uses to which this water will be put is beyond the scope of this report. Relatively constant temperature and good chemical quality make the water suitable for use by many industries, from trout rearing to production of electronic components.

At the 1963 rate of construction, the number of high-capacity wells will double by 1966 . If average yields remain the same and the number of wells doubles, approximately 150,000 acre-feet of water will be pumped during 1966. As recharge remains constant and underflow and streamflow are approximately constant, the decline of water levels will be directly proportional to the amount of water pumped by wells; therefore, the monitoring of observation wells is necessary to dolineate 
areas of excessive decline and to help evaluate aquifer characteristics in more detail.

The total land under irrigation in 1962 was about 57,000 acres. At that time, only about 2 percent of the irrigable area was irrigated. Development of all irrigable land underlain by a saturated thickness greater than 50 feet-that is, 2.5 million acres-would recuire 20,000 wells. If maximum unplanned development is reached in the High Plains of Colorado, severe problems of interference between wells, increased pumping lifts, and lowered yields will result. Most of these problems can be minimized, however, by sound planning and proper management.

Workable development and management plans require adequate knowledge of the hydrologic system. The summary of the system given in this report allows for preliminary development and management planning. As development continues, however, modifying and complicating the hydrologic system, any plans based on the present data soon will become outdated. Studies to collect and aralyze data continually are therefore essential.

Studies that merely collect and analyze data will be insufficient to meet the needs of a greatly expanded economy. Policy makers and planners will demand studies that include alternate plans for management and development and predictions of their effects on future water supplies.

The accuracy of predictions about any proposed derelopment plan and its effect on the future water supply of the area will depend on the quality and amount of data available. Although the hydrologic system as a whole has been evaluated, specific parts of the system have not. More precise knowledge is needed as to the amount of recharge and its distribution, the amount of evaporation, and the magnitude and areal distribution of transmissibility and storage.

Recharge to the Ogallala Formation differs greatly from one part of the area to another. Recharge figures used in this report are only approximate. Field instrumentation in the dune-sand, loess, and ephemeral stream areas and additional data collection will make computations of recharge more accurate. Much of his information can be used to compute evaporation and transpiration.

The coefficients of storage and transmissibility are usually computed from short-term aquifer tests. Long-term tests (60-90 days), however, should yield much more accurate results.

To predict the hydrologic budget accurately, the following steps are necessary :

Recharge:

1. Refinement of methods by instrumentation.

2. Evaluation of artificial-recharge techniques. 
3. Deterination of areal distribution of ephemeral streams, dune sand, and loess.

Discharge :

1. Determination of surface flow and underflow out of the State.

2. Maintenance of accurate records of pumping.

Erapotianspiration:

1. Determination of evaporation rate.

2. Refinement of consumptive-use estimates.

Storage changes:

1. Monitoring of water-level fluctuations.

2. Accurate determination of storage coefficient.

As irrigation increases, water quality may deteriorate, because during irrigation a part of the water and most of the salts return to the aquifer, and over a period of time the salt concentration of the ground water can increase to a harmful level. To detect variations in quality, water samples should be collected annually from selected wells.

\section{SELECTED REFERENCES}

Blaney, H. F., and Criddle, W. D., 1950, Determining water requirements in irrigated areas from climatological and irrigation data: U.S. Dept. Agriculture, Soil Conserv. Service Tech. Paper 96, 48 p.

Boettcher. A. J., 1962, Records, logs, and water-level measurements of selected wells and test holes and chemical analyses of ground water in eastern Cheyenne and Kiowa Counties, Colorado: Colorado Water Conserr. Board Basic-Data Rept. 13, 18 p.

1963, Prospects for irrigation in eastern Cheyenne and Kiowa Counties, Colorado: Colorado Water Conserv. Board Circ. 7, 12 p.

1964, Geology and ground-water resources of eastern Cheyenne and Kiowa Counties, Colorado: U.S. Geol. Survey Water-Supply Paper 1779-N, p. N1-N32.

Cardwell, W. D. E., 1953, Irrigation-well development in the Kansas River basin of eastern Colorado: U.S. Geol. Survey Circ. 295, 72 p.

Cardwell. W. D. E., and Jenkins, E. D., 1963, Gound-water geology and pump irrigation in Frenchman Creek basin above Palisade, Nebraska : U.S. Geol. Surrey Water-Supply Paper 1577, 472 p.

Chase, G. H., 1956, Preliminary maps of depth to water, water-table contour, saturated thickness, contour of the surface of the Pierre Shale, and depth to bedrock, Kit Carson County, Colorado: U.S. Geol. Survey open-file maps $1,2,4.5,6$.

Chase, G. H., Burtis, V. M., and Major, T. J., 1962, Records, logs, and waterlevel measurements of selected wells and test holes, description of the physical properties of representative formation materials, and chemical anal$y$ ses of ground water in Kit Carson County, Colorado: Colorado Water Conserv. Board Basic-Data Rept. 10, 69 p.

Cronin, J. G., and Wells, L. C., 1963, Geology and ground-water resources of Hale County, Texas: U.S. Geol. Survey Water-Supply Paper 1E39-U, p. U1-U38. 
Darton, N. H., 1905, Preliminary report on the geology and underground water resources of the central Great Plains: U.S. Geol. Survey Prof. Paper 32, $433 \mathrm{p}$.

Elias, M. K., 1931, The geology of Wallace County, Kansas: Kansas State Geol. Survey Bull. 18, 254 p.

Fenneman, N. M., 1931, Physiography of Western United States: New York, McGraw-Hill Book Co., 534 p.

Ferris, J. G., Knowles, D. B., Brown, R. H., and Stallman, R. W., 1962, Theory of aquifer tests: U.S. Geol. Survey Water-Supply Paper 1536-E, p. 69-174.

Frolik, E. F., 1963, Summary of results of the Nebraska tractor tests : Nebraska Univ. Agr. Expt. Sta., 1 sheet.

Gregg, D. O., Meyer, E. L., Targy, M. M., and Moulder, E. A., 1961, Public water supplies of Colorado, 1959-60: U.S. Geol. Survey and Colorado State Univ. Agr. Expt. Sta., Gen Ser. 757, 128 p.

Hay, Robert, 1895, Water resources of a portion of the Great Plains: U.S. Geol. Survey 16th Ann. Rept., pt. 2, p. 535-588.

Johnson, W. D., 1901, The High Plains and their utilization: U.S. Geol. Survey 21st Ann. Rept., pt. 4, p. 601-741.

1902, The High Plains and their utilization [conclusion of raper in 21st Ann. Rept., pt. 4] : U.S. Geol. Survey 22d Ann. Rept., pt. 4, p. 631-669.

Judson, S. S., Jr., 1950, Depressions of the northern portion of the southern High Plains of eastern New Mexico: Geol. Soc. America Bull., v. 61, no. 3, p. 253-274.

McGovern, H. E., 1961, Records, logs, and water-level measurements of selected wells and test holes, and chemical analyses of ground water in Washington County, Colorado: Colorado Water Conserv. Board Basic-Data Pept. 6, 26 p.

1964, Geology and ground-water resources of Washington County, Colorado: U.S. Geol. Survey Water-Supply Paper 1777, 46 p.

McGovern, H. E., and Coffin, D. L., 1963, Potential ground-water derelopment in the northern part of the Colorado High Plains: Colorado Water Conserv. Board Circ. 8, 8 p.

Moulder, E. A., 1960, Ground water in the Ogallala and several consplidated formations in Colorado: Colorado Water Conserv. Board Circ. 5, $8 \mathrm{r}$.

Moulder, E. A., and Frazor, D. R., 1957, Artificial recharge exreriments at McDonald well field, Amarillo, Texas: Texas Board Water Engineers Bull. $5701,34 \mathrm{p}$.

U.S. Public Health Service, 1962, Drinking water standards: U.S. P blic Health Service Pub. 956, 61 p.

U.S. Salinity Laboratory Staff, 1954, Diagnosis and improvement of saline and alkali soils: U.S. Dept. Agriculture Handb. 60, 160 p.

Voegeli, P. T., Sr., and Hershey, L. A., 1960, Records and logs of seceted wells and test holes, and chemical and radiometric analyses of griund water, Prowers County, Colorado: Colorado Water Conserv. Board Basic-Data Rept. 1, 52 p.

- 1965, Geology and ground-water resources of Prowers Count., Colorado: U.S. Geol. Survey Water-Supply Paper 1772, 101 p.

Weist, W. G., Jr., 1960, Records and logs of selected wells and test holes, and chemical analyses of ground water, Yuma County, Colorado: Colorado Water Conserv. Board Basic-Data Rept. 2, 41 p.

1964, Geology and ground-water resources of Yuma County, Colorado: U.S. Geol. Survey Water-Supply Paper 1539-J, p. J1-J56. 


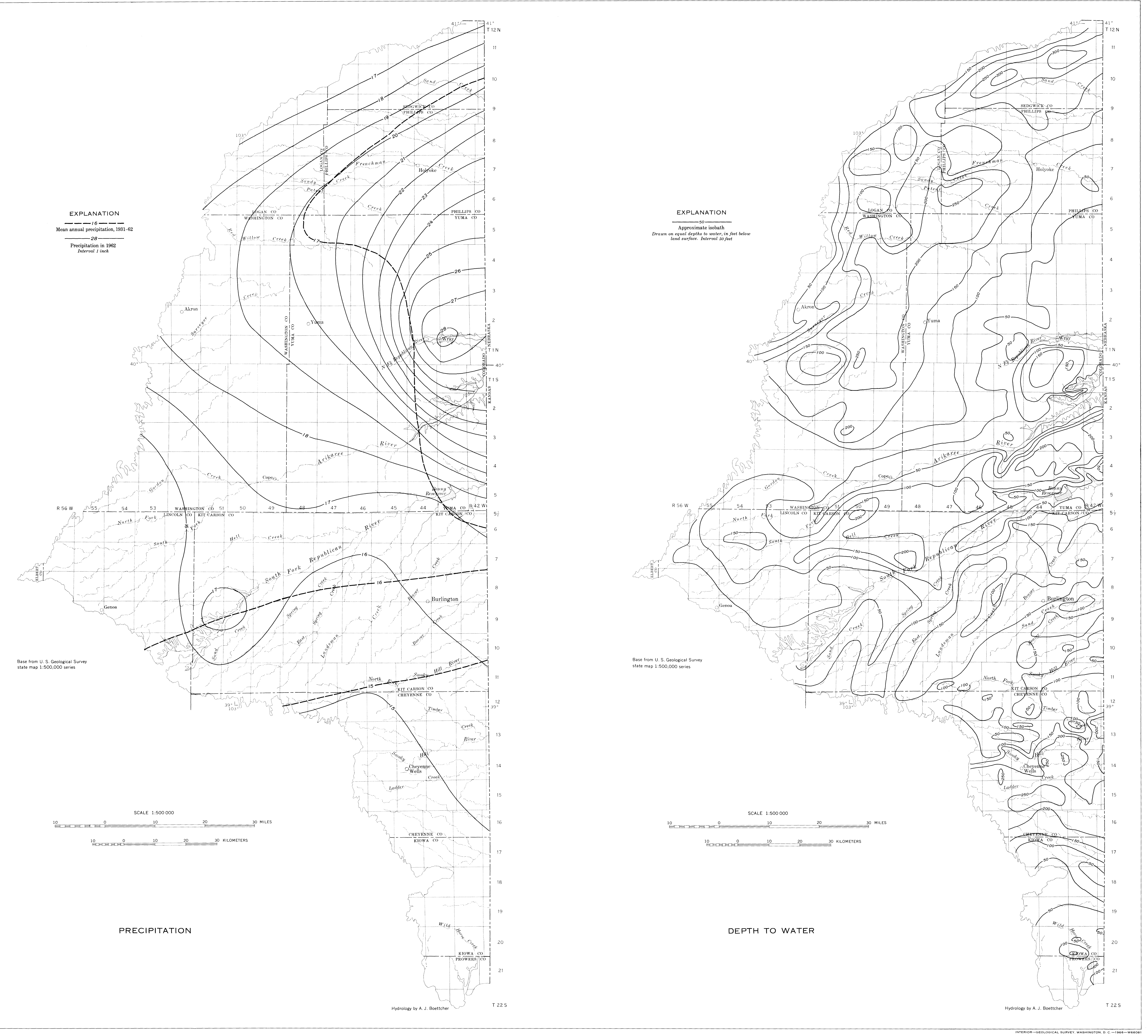




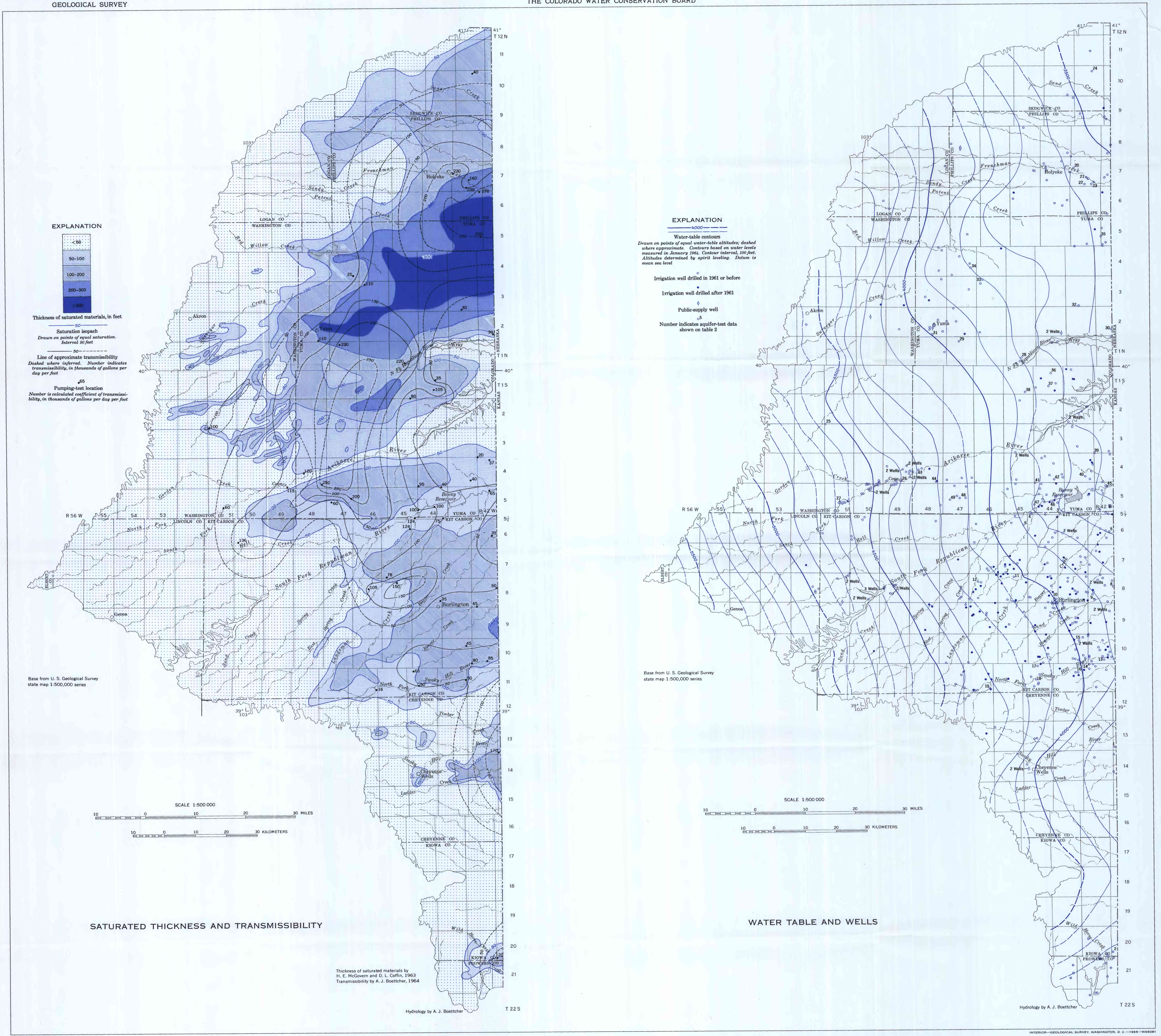




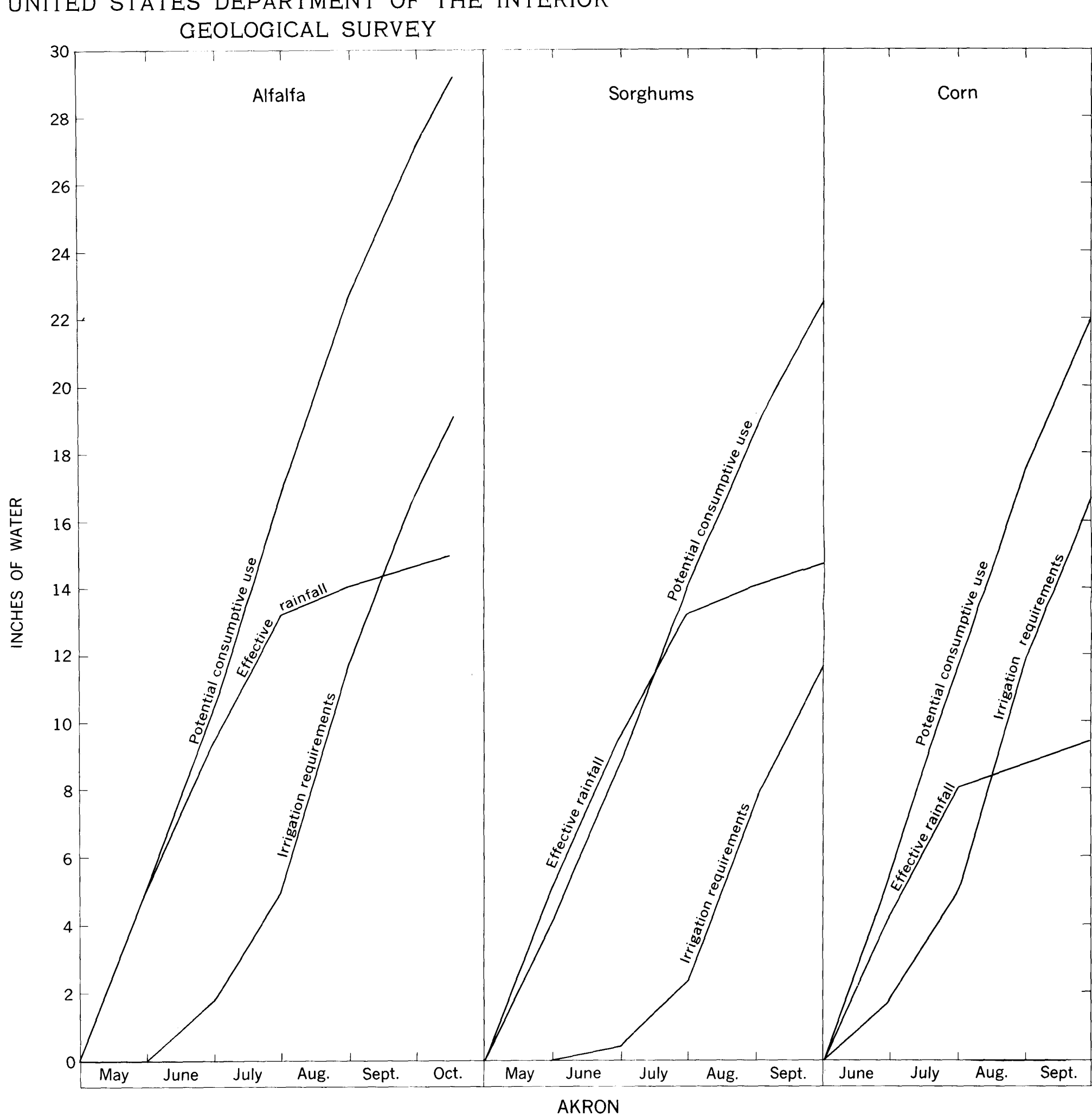

WATER-SUPPLY PAPER 1819-I
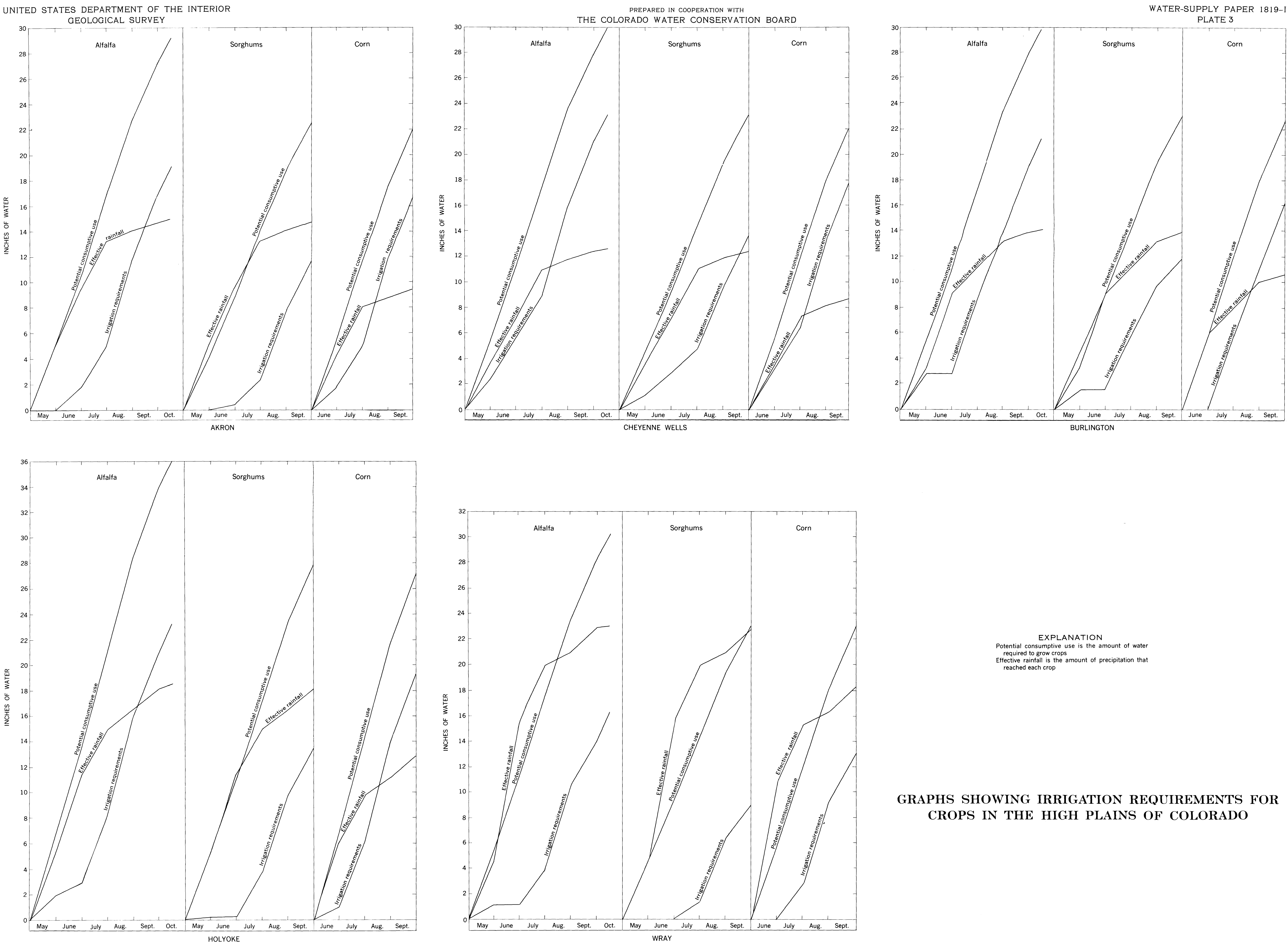

GRAPHS SHOWING IRRIGATION REQUIREMENTS FOR CROPS IN THE HIGH PLAINS OF COLORADO 